\title{
DISTRIBUTION OF HEPATITIS C VIRUS (HCV) GENOTYPES IN SEROPOSITIVE PATIENTS IN THE STATE OF ALAGOAS, BRAZIL
}

\author{
Rosa Maria S. Gonzaga ${ }^{1}$; Itatiana F. Rodart² ${ }^{2}$ Mitermayer Galvão Reis ${ }^{2}$; Cícero Eduardo Ramalho Neto ${ }^{1}$; \\ Denise Wanderlei Silva ${ }^{3 *}$
}

${ }^{1}$ Laboratório de Genética Molecular, Genômica e Proteômica, Universidade Federal de Alagoas, Maceió, AL, Brasil; ${ }^{2}$ Laboratório de Patologia e Biologia Molecular, Centro de Pesquisas Gonçalo Moniz, Fundação Oswaldo Cruz, Salvador, BA, Brasil;

${ }^{3}$ Laboratório de Microbiologia Molecular, Setor de Microbiologia, Parasitologia e Patologia, Instituto de Ciências Biológicas e da Saúde, Universidade Federal de Alagoas, Maceió, AL, Brasil

Submitted: October 08, 2007; Returned to authors for corrections: February 25, 2008; Approved: November 02, 2008.

\section{SHORT COMMUNICATION}

\begin{abstract}
We determined the frequency of hepatitis $\mathrm{C}$ virus (HCV) genotypes in anti-HCV seropositive patients in the state of Alagoas, Brazil, by means of nested-reverse transcription-polymerase chain reaction (RT-nestedPCR) followed by restriction fragment length polymorphism (RFLP) of amplified fragments of the 5 'NCR. The nested-PCR with genotype-specific primers from the core region was carried out when detection was not possible by the first approach. Detectable HCV-RNA was present in 115 (74.7\%) of 154 serum samples. Genotype 1 was the most frequent (77.4\%), against $20.9 \%$ of genotype 3 and $0.8 \%$ of genotype 2 . Subtype $1 \mathrm{~b}$ was predominant $(65.2 \%)$, followed by subtypes $1 \mathrm{a}(8.7 \%)$, and $3 \mathrm{a}(6.1 \%)$. Coinfection $(1 \mathrm{a} / 3 \mathrm{a})$ was detected in $0.8 \%$ of the samples. Indeed, there was no significant differences in the prevalence of genotype 1 compared to what has been obtained from anti-HCV seropositive patients from other locations in Brazil. Here we report for the first time the genotype 2 in the state of Alagoas.
\end{abstract}

Key words: Hepatitis C virus, 5'NCR, core region, RT-nested-PCR, genotypes

Hepatitis $\mathrm{C}$ virus (HCV) is a major cause of parenterally transmitted hepatitis (17) and has become a major emerging infectious disease problem, whereas it has been estimated that $3 \%$ of the world population (14) are infected with the virus.

Infection by the virus $\mathrm{C}$ could lead to chronicity in $85 \%$ of the cases, with possible progression to hepatocellular carcinoma (HCC), or complications requiring liver transplantion, such as liver cirrhosis (13).

There is an extensive genetic heterogeneity among different $\mathrm{HCV}$ strains (21), with at least six major genotypes further divided into subtypes (12), whose frequency and incidence in the population seem to be variable both geographically and temporally due to the distribution and evolution of risk factors (17).
Previous data about the frequencies of HCV genotypes in different geographical regions of Brazil (2) found types 1, 2, 3, 4, and 5 in samples from 1,688 patients with chronic hepatitis C. In all regions genotype 1 was the most frequent, whereas types 4 and 5 were rare and detected only in the Southeast. However, genotype 4 of the virus was recently described in Salvador, Bahia, Northeastern area of Brazil (19).

Studies have suggested that genotypes 1, especially subtype $1 \mathrm{~b}$, and 4 are associated with a less favorable outcome after interferon (INF) therapy $(4,18)$. It has been also determined that patients infected with these genotypes and with viral loads higher than $800,000 \mathrm{UI} / \mathrm{mL}$ should be treated for one year, whereas patients with genotype 2 or 3 , may be treated for only 6 months, in spite of the viremia degree $(5,22)$.

*Corresponding Author. Mailing address: Setor de Microbiologia, Parasitologia e Patologia, Instituto de Ciências Biológicas e da Saúde, Universidade Federal de Alagoas, Praça Afrânio Jorge, s/n. Prado. 57020-720. Maceió, AL, Brasil. Telefax: +55 823221 2105. E-mail: dmws@ccbi.ufal.br 
To our knowledge, the only information about the prevalence of HCV genotypes in the State of Alagoas, northeastern Brazil, is based on 28 samples (2), where the investigators found 23 of them infected with genotype 1 and five with genotype 3 , but none have been reported for subtypes.

Therefore, the objective of the present study was to use a larger number of samples in order to determine the prevalence of genotypes of the virus circulating in anti-HCV seropositive patients in the state of Alagoas. We used a nested-reverse transcription-polymerase chain reaction (RT-nested-PCR) followed by restriction fragment length polymorphism (RFLP) of amplified fragments of the 5'NCR and genotype-specific primers from the core region when genotyping was not possible by the first approach.

We evaluated sera from 154 anti-HCV seropositive patients (age range $=18-72$ years; male:female ratio $=121: 33$ ) who attended the Day Hospital of University of Alagoas (UFAL) and Central Laboratory of Alagoas (LACEN), in Maceió, Alagoas state, Brazil, between January 2003 to December 2005. The project was approved by the Institution ethical committee of the University of Alagoas and informed consent was obtained from each subject. RNA isolation from $200 \mu \mathrm{L}$ of serum was performed using a commercial viral RNA isolation kit TRIzol ${ }^{\circledast} L S$ Reagent (Life Technologies ${ }^{\mathrm{TM}}$ ) following manufacturer's instructions. Singlestranded cDNA was immediately synthesized by using reverse transcription of the RNA sample with 200U of Moloney murine reverse transcriptase (MMLV), $2 \mu \mathrm{M}$ of random primer, $0.4 \mathrm{mM}$ of each dideoxynucleotide (dNTP), $8 \mu \mathrm{M}$ of dithiothreitol (DTT), 10U RNAsin, and $1 \mathrm{X}$ supplied PCR buffer. cDNA amplification by amplification-polymerase chain reaction (RT-PCR) and HCV genotyping was performed by two systems. In the first one, based on Chan et al. (3), a first-round PCR was carried out with primers 939 and 209, whereas in the second-round PCR, primers 940 and 211. HCV genotyping and subtyping were accomplished by double digestion of the nested PCR products with HaeIII-RsaI and Hinfl-MvaI. Samples with pattern consistent with type 1 were further digested with $B s t \mathrm{UI}$, and of type 2 or 3 with $S c r F I$. The second system was based on Lerat et al. (7), which was used when detection was not possible by the first approach. The first PCR was performed using the antisense primer 186 NTER and the amplified product was subjected to a second PCR. Combinations of primers 104/132Nbis, 104/123Nbis, 1041IIa/134Nbis1-2, 104IIIa/ $339 \mathrm{Nbis}$, and $104 \mathrm{IVa} / 465$ generated product sizes corresponding to genotypes/subtypes 1a, 1b, 2, 3a, and 4a, respectively. In both systems, PCR products were analysed by electrophoresis on a $4 \%$ metaphor agarose gel and stained with ethidium bromide.

Hepatitis $\mathrm{C}$ accurate genotyping has been shown to have an important role in epidemiological studies and clinical setting of the liver disease. HCV-RNA was detected in serum samples from 115 out of 154 patients (74.7\%). The frequency of HCVRNA from anti-HCV-positive patients was similar to that reported in other studies $(1,2,6,9,11)$.
The overall distribution of HCV genotypes and subtypes from patients attending the Day Hospital of University of Alagoas (UFAL) and Central Laboratory of Alagoas (LACEN) is summarized in Table 1.

It has been suggested that the pattern of HCV genotypes distribution in Brazil is similar to the one found in many European countries, with prevalence of types 1 and 3 , with epidemiological behavior typical of an exponential spread in recent years, probably through blood transfusions (2).

Here, genotypes 1, 2, and 3 of the virus were found among the $115 \mathrm{HCV}-\mathrm{RNA}$ positive samples evaluated, where genotype 1 was by far the most frequent (77.4\%), followed by genotype 3 (20.9\%), genotype $2(0.8 \%)$, and mixed infection $1 \mathrm{a} / 3 \mathrm{a}(0.8 \%)$. Indeed, there was no substantial differences in prevalence of genotype 1 compared to frequencies obtained from anti-HCV positive patients in other Brazilian locations $(6,8,11,13)$.

In a study carried out to investigate $\mathrm{HCV}$ prevalence in different regions of Brazil (2), genotype 1 was predominant, with lower frequency of the genotype in the Southern region (Rio Grande do Sul), 37.5\%, when compared to the other regions, whose prevalence ranged from 50 to $82.2 \%$. In the Northeastern population the authors found genotype 1 the most prevalent, with higher frequency in Alagoas (82.1\%), comparable to the one found in our study results using a larger number of samples.

Here we report for the first time genotype 2 in the state of Alagoas. However, the prevalence of the genotype was lower to those previously reported in other geographic regions of Brazil, 2.4\% in Pernambuco (2), 6.7\% in Bahia (20), 1.6\% in Paraná (16), as well as $25.8 \%$ in Mato Grosso and $62.5 \%$ in Rio Grande do Sul (2).

Campiotto and colaborators (2) found that the frequency of genotype 3 varied among the different Brazilian regions, with its highest value in Santa Catarina (50\%) and Paraná (41.7\%), Southern region, as well as Goiás, Center-West region, (37.1\%), and Pernambuco (36.9\%), Northeast region. In our study, the frequency of genotype was similar to the one obtained the investigators for the state $(17.9 \%)$.

Genotype 1 is predominant worldwide and is comprised of two major subtypes, $1 \mathrm{a}$ and $1 \mathrm{~b}(9,15)$. Furthermore, it has been demonstrated that the growth rates of these subtypes are greater than those of genotypes 4 and 6 (10).

In our population, the prevalence of subtype $1 \mathrm{~b}(65.2 \%)$ was higher than what was observed in Salvador, Bahia state (11), where the subtype only occurred in $38.6 \%$ of the antiHCV-positive samples. However, it is very similar to the results obtained from HCV seropositive samples from the Brazilian states of Acre, Amazonas, and Pará (North region), as well as from Bahia and Pernambuco, with frequencies of $60 \%$ and $71 \%$ for each region, respectively (8).

Despite not being reported frequently, one sample had a mixed pattern $1 \mathrm{a} / 3 \mathrm{a}$, what could be explained by mutations in the core region or by coinfection (11). In our study, subtypes 
Table 1. Distribution of Hepatitis C virus genotypes in seropositive patients in the sate of Alagoas, Brazil

\begin{tabular}{|c|c|c|c|c|c|c|c|}
\hline \multicolumn{8}{|c|}{ No. $(\%)$ of isolates of the genotypes } \\
\hline \multicolumn{3}{|c|}{ Type 1} & Type 2 & \multicolumn{2}{|c|}{ Type 3} & \multirow{2}{*}{$\begin{array}{l}\text { Mixed } \\
(1 \mathrm{a} / 3 \mathrm{a})\end{array}$} & \multirow[t]{2}{*}{ All } \\
\hline 1a & $1 \mathrm{~b}$ & Undet. $^{\mathrm{a}}$ & (2a) & $3 a$ & Undet. $^{\mathrm{a}}$ & & \\
\hline $10(8.7)$ & $75(65.2)$ & $4(3.5)$ & $1(0.8)$ & $7(6.1)$ & $17(14.8)$ & $1(0.8)$ & $115(100.0)$ \\
\hline
\end{tabular}

a Undetermined= subtype no further determined.

related to four genotype $1(3.5 \%)$ and 17 genotype $3(14.8 \%)$ could not be determined by the methods used.

Brazil Health Ministry recommends the accurate identification of infecting $\mathrm{HCV}$ in order to distinguish genotype 1 and 4 from the others, thus limiting costs and improving clinical outcomes. Therefore, this study demonstrates that genotype 1 was the most frequent (77.4\%) in Alagoas, which will require longer antiviral therapy.

\section{ACKNOWLEDGMENTS}

This work was supported by the National Counsel of Technological and Scientific Development (CNPq), Research Foundation for the State of Alagoas (Fapeal), and Brazil Health Ministry (MS).

\section{RESUMO}

\section{Distribuição de genótipos do Vírus da hepatite $C$ (HCV) em pacientes soropositivos no Estado de Alagoas, Brasil}

A frequência de genótipos do vírus da hepatite $\mathrm{C}(\mathrm{HCV}) \mathrm{em}$ pacientes soropositivos anti-HCV no estado de Alagoas, Brasil, foi determinada através da RT-PCR aninhada da região 5 'NCR seguida pela análise do polimorfismo de comprimento dos fragmentos de restrição (RFLP). A RT-PCR aninhada utilizando primers genótipo-específicos da região core foi efetuada quando não foi possível determinar o genótipo pelo primeiro método. Níveis detectáveis de HCV-RNA estavam presentes em 115 $(74,7 \%)$ das 154 amostras de soro. O genótipo 1 foi o mais freqüente $(77,4 \%)$, contra $20,9 \%$ do genótipo 3 e $0,8 \%$ do genótipo 2 . O subtipo $1 \mathrm{~b}$ foi predominante $(65,2 \%)$, seguido pelos subtipos 1a $(8,7 \%)$ e $3 a(6,1 \%)$. Co-infecção $(1 \mathrm{a} / 3 \mathrm{a})$ foi detectada em $0,8 \%$ das amostras. Não foram encontradas diferenças significativas quanto à prevalência do genótipo 1 em relação ao que tem sido obtido de pacientes soropositivos anti-HCV de outras localidades do Brasil. Este é o primeiro relato da presença do genótipo 2 no estado.

Palavras-chave: Vírus da hepatite C, 5'NCR, região core, RTPCR aninhada, genótipos

\section{REFERENCES}

1. Bezerra, C.S.; Lima, M.C.; Vilar, J.L.; Moreira, J.L.B.; Frota, C.C. (2007). Viral hapatitis $C$ in a leading Brazilian hospital: epidemiological factors and genotyping. Braz. J. Microbiol., 38 (4), 656-666.

2. Campiotto, S.; Pinho, J.R.R.; Carrilho, F.J.; Da Silva, L.C.; Souto, F.J.D.; Spinelli, V.; Pereira, L.M.M.B.; Coelho, H.S.M.; Silva, A.O.; Fonseca, J.C.; Rosa, H.; Lacet, C.M.C.; Bernardini, A.P. (2005). Geographic distribution of Hepatitis C virus genotypes in Brazil. Braz. J. Med. Biol. Res., 38 (1), 41-49.

3. Chan, S.W.; McOmish, F.; Holmes, E.C.; Dow, B.; Peutherer, J.F.; Follet, E.; Yap, P.L.; Simmonds, P. (1992). Analysis of a new hepatitis $\mathrm{C}$ virus type and its phylogenetc relationship to existing variants. $J$. Gen. Virol., 73 (Pt 5), 1131-1141.

4. Davis, G.L.; Lau, J.Y. (1997). Factors predictive of a beneficial response to therapy of hepatitis C. Hepatol., 26 (3 Suppl 1), 122S$127 \mathrm{~S}$.

5. EASL International Consensus Conference on Hepatitis C. (1999). Consensus statement. J. Hepatol., 31 (Suppl 1), 3-8.

6. Gonçalves, P.L.; Cunha, C.B.; Busek, S.C.U.; Oliveira, G.C.; RibeiroRodrigues, R.; Pereira, F. (2005). Detection of hepatitis C virus RNA in saliva samples from patients with seric anti-HCV antibodies. Braz. J. Infect. Dis., 9 (1), 28-34.

7. Lerat, H.; Rumin, S.; Habersetzer, F.; Berby, F.; Trabaud, M.A.; Trépo, C.; Inchauspé, G. (1998). In vivo tropism of hepatitis C virus genomic sequences in hematopoietic cells: Influence of viral load, viral genotype, and cell phenotype. Blood, 91 (10), 3841-3849.

8. Lunge, V.R.; Ikuta, N.; Fonseca, A.S.K.; Marques, E.K.; Cheinquer, H. (1999). Prevalence of hepatitis C virus genotypes in north and northeast regions from Brazil. XX World Congress of Pathology and Laboratory Medicine, São Paulo, SP, Brazil, p. 81-86.

9. Oliveira, M.L.A.; Bastos, F.I.; Sabino, R.R.; Paetzold, U.; Schreier, E.; Pauli, G.; Yoshida, C.F.T. (1999). Distribution of HVC genotypes among different exposure categories in Brazil. Braz. J. Med. Biol. Res., 32 (3), 279-282.

10. Pybus, O.G.; Charleston, M.A.; Gupta, S.; Rambaut, A.; Holmes, E.C.; Harvey, P.H. (2001). The epidemic behavior of the hepatitis C virus. Science, 292 (22), 2323-2325.

11. Silva, L.K.; Paraná, R.; Souza, S.P.; Berby, F.; Kay, A.; Trépo, C.; Santana, N.; Cotrim, H.; Lyra, L.G; Reis, M.G. (2000). Hepatitis C virus genotypes in a northeastern area of Brazil. Am. J. Trop. Med. Hyg., 62 (2), 257-260.

12. Simmonds, P.; Alberti, A.: Alter, H.J. Bonino, F.; Bradley, D.W.; Brechot, C.; Brouwer, J.T.; Chan, S.W.; Chayama, K.; Chen, D.S.; Choo, Q.-L.; Colombo, M.; Cuypers, H.T.M.; Date, T.; Dusheiko, G.M.; Esteban, J.I.; Fay, O.; Hadziyannis, S.J.; Han, J.; Hatzakis, A; Holmes, E.C.; Hotta, H.; Houghton, M.; Irvine, B.; Kohara, M.; Kolberg, J.A.; Kuo, G.; Lau, J.Y.N.; Lelie, P.N.; Maertens, G.; McOmish, F.; Miyamura, T.; Mizokami, M.; Nomoto, A.; Prince, A.M.; Reesink, H.W.; Rice, C.; Roggendorf, M.; Schalm, S.W.; Shikata, T.; Shimotohno, K.; Stuyver, L.; Trépo, C.; Weiner, A.; 
Yap, P.L.; Urdea, M.S. (1994). A proposed system for the nomenclature of hepatitis C viral genotypes. Hepatol., 19 (5), $1321-1324$

13. Souza, M.; Paraná, R.; Trépo, C.; Barbosa-Jr, A.A.; Oliveira, I.R.; Andrade, Z.A. (2001). Effect of interferon-alpha on experimental fibrosis of the liver-study with a new model. Mem. Inst. Oswaldo Cruz, 96 (3), 343-348.

14. Strauss, E. (2001). Hepatite C. Rev. Soc. Bras. Med. Trop. 34 (1), 69-82.

15. Takahashi, M.; Yamada, G.; Miyamoto, R.; Doi, T.; Endo, H.; Tsuji, T. (1993). Natural course of chronic hepatitis C. Am. J. Gastroenterol., 88 (2), 240-243.

16. Vogler, I.H.; Nishiya, A.; Morimoto, H.K.; Reiche, E.M.V.; Bortoliero, A.L.; Matsuo, T.; Sabino, E.C.; Vaz, A.J. (2004). Serological, epidemiological and molecular aspects of hepatitis $\mathrm{C}$ virus infection in a population from Londrina, PR, Brazil, 2001-2002. Rev. Inst. Med. Trop. São Paulo, 46 (6), 303-308.
17. Wasley, A.; Alter, M.T. (2000). Epidemiology of hepatitis C: geographic differences and temporal trends. Semin. Liver Dis., 20 (1), 1-16.

18. Webster, G.; Barnes, E.; Brow, D.; Dusheiko, G. (2000). HCV genotyesrole in pathogenesis of disease and responde to therapy. Baillieres Best Pract. Res. in Clin. Gastroenterol., 14 (2), 229-240.

19. Zarife, M.A.S; Oliveira, E.C.P.; Romeu, J.M.S.L.; Reis, M.G. (2006) Detecção do genótipo 4 do vírus da hepatite C em Salvador, Bahia. R. Soc. Bras. Med. Trop., 39 (6), 567-569.

20. Zarife, M.A.S.; Silva, L.K.; Silva, M.B.; Lopes, G.B.; Barreto, M.L.; Teixeira, M. da G.; Dourado, I.; Reis, M.G. (2006). Prevalence of Hepatitis $\mathrm{C}$ virus infection in north-eastern Brazil: a populationbased study. Trans. R. Soc. Trop. Med. Hyg., 100 (7), 663-668.

21. Zein, N.N. (2000). Clinical significance of hepatitis $C$ virus genotypes. Clin. Microbiol. Rev., 13 (2), 223-235.

22. Zylberberg, H.; Chaix, M.L.; Bréchot, C. (2000). Infection with hepatitis $\mathrm{C}$ virus genotype 4 is associated with a poor response to interferon alpha. Ann. of Intern. Med., 132 (10), 845-846. 